\title{
Lecturer's Perspective on Talent Management in Private Higher Learning Institutions in Kuala Lumpur, Malaysia
}

\author{
Mahiswaran Selvanathan ${ }^{1}$, Nisha Nair Surendran ${ }^{2}$, Thilageswary Arumugam ${ }^{2}$, Sri Jeyanthirar Subramaniam ${ }^{1} \&$ \\ Noraini Mohamad Yusof ${ }^{1}$ \\ ${ }^{1}$ National Higher Education Research Institute (IPPTN), Universiti Sains Malaysia, Malaysia \\ ${ }^{2}$ Asia Pacific University (APU), Malaysia
}

Correspondence: Mahiswaran Selvanathan, National Higher Education Research Institute (IPPTN), Universiti Sains Malaysia, Malaysia. E-mail: mahiswaran@gmail.com

Received: July 21, 2019

doi:10.5430/ijhe.v8n5p257
Accepted: October 16, 2019

Online Published: October 19, 2019

\begin{abstract}
Talent management has been an ongoing focus in teaching and career development among lecturers in universities. However, this effective practice lies in the conduct of certain factors in an organisation. Some of the important factors that contribute to talent management of an organisation are; the ability of lecturers to perform, organizational culture and retention practice of an organisation. Hence, this paper took a milestone in explaining the relationship among talent management and three antecedent factors; performance, organisational culture and retention. Importantly, the research focuses on academicians who are teaching Information Technology related subjects. The leading universities in Malaysia have a tendency to lose competent academicians thus creating a gap in the organisational outcome. Thus, respondents were sampled from Private Higher Learning Institutions in Kuala Lumpur, Malaysia. The data was collected from 133 respondents who have been teaching in IT related modules. Hypotheses were built based on the relationship between variables and analysed using Pearson Correlation in via the SPSS software. The results show-that two hypotheses are not supported except for one of the hypothesis on retention has indicated a significant relationship with the talent management practice of the university. Information Technology is a fast growing industry as lecturers in this field need to be constantly updated in their knowledge, skills and ability. This requires talent management. Academicians who are unable to do this with the support and motivation of an organisation may not be able to offer their services in the university. Consequently, this can lead to poor outcome on knowledge delivery to students or the turnover rate may be affected. Overall, this paper has called for good human resource practices for lecturers in the teaching profession.
\end{abstract}

Keywords: lecturer, talent management, performance, organisational culture, retention

\section{Introduction}

Talent management is an important essence that needs to be managed effectively in order to accomplish the organisation's missions and objectives. Most of the organisations set a priority for talent management in their organisation so as to thrive for its excellence (Kwame, 2015). Naim and Lenka (2017) advocate that, talent management has become a serious challenge in Human Resource Management (HRM) as there is a need to have suitable approaches and actions to enhance the talent management entity in the emerging fast growing markets. The evolving business environment and changing in business trends have created a space for high talent mobility. Most of the organizations acknowledge the importance of managing talents among the lecturers in their respective universities. However, the reality is that importance is only given towards the professional status and the salary of its staff (Van, 2013). It is also important to note that talent management is an important aspect for the effectiveness of an organisation, the management of organisation needs to engage, retain and develop talents to support the growing skilled labour demands. Growing attention to talent is pretentious which includes aspects that encompasses knowledge-based competition, globalisation, changing the world of work as well as a new form of demographic changes and organisations (Van, 2013). This has thrust forward the criticality of talent management in the development of manpower. One of factors that the study analysed is the lecturers' performance as the main strategic agenda in HRM of many organisations and currently reinforced by a trend of the companies converting from a collegial to a managerial model. 
Lecturers' performance remained as the factor that needs to be observed for an organisation in order to-improve their talent management practices. Multi-dimensional concepts have made the lecturers' performance to be measured on relative, task, adaptive and counterproductive behaviours (Nisada, 2016). For organisational culture, Oladapo (2014) pointed that the influence of culture in talent management is quite captivating. Talent management could deliver a technique in simplifying the tools by emphasising on the resources while improving its tool on key talent management which is on-going. (Mohamed \& Shiekh Abukar, 2013). Organisational culture plays an important role on the execution of talent management (Fanxing, 2016). For instance, talent management encourages the talented lecturers to blend with an organisational culture. According to Cutajar (2012), approach to talent management could extremely affect the native values of multinational and small companies toward the progress of their organisation. Another factor that the study evaluates is the lecturers' retention as one of the primary concerns of the management of an organisation.

Lecturers' retention is seen as an opportunity for many organisations to sustain a competitive workforce (Oladapo, 2014). Retaining and attracting a talented workforce impresses the Vice Presidents of an organisation to think on the opportunities and possibilities as offers such as benefits and compensation, good work culture, teamwork and balance between work life and personal life could encourage the organisation's retention (Hughes \& Rog, 2012). The government mentioned that Malaysia has become a global IT hub through the expansion of the Multimedia Super Corridor (MSC) flagship project, the advancement of Malaysia's IT infrastructure and telecommunications and the computerisation of several ministries and agencies (Trequattrini \& Shams, 2016). Since then, it shows great growth and sectorial shares in the Malaysian IT which has contributed towards the change to smaller ICT from traditional computers devices. On the contrary, most of the start-up organisations in Malaysia do not know how to retain talented lecturers in an organisation (Mishra \& Chih, 2015). Talent management shows that the IT department has the competence to advance the dynamic capability of TM (Benitez, 2015). Through the IT department, the firm delivers exact and timely information to the market to recruit and to get on board excellent talents to design and adapt its talent base. Companies such as Petronas, Maxis and other companies mostly practice on social networking to attract talents. The websites such as LinkedIn, Facebook and Twitter help to recruit and manage talents. Likewise, combination for human resource boards and social network will enable the IT organisations to select talents with quicker methods since there are many candidates who are available for a particular job. IT departments may enhance the work culture and thus refine its talent management (Ahlan et al, 2014). According to a report published by the Department of Statistic Malaysia in 2016, there were about 2,964 foreign lecturers working in Malaysia as compared to 2,950 in 2015. The manufacturing sector continued to contribute around 57.1 percent followed by the service sector with a share about 34.4 percent. The report also highlighted foreign controlled companies over 50 percent of the equity. Alias et al (2014) highlighted that the IT employers preferred to recruit foreign lecturers as there is a lack of local experts in the area. Accumulatively, there are about 21.4 percent of local experts in IT, however, most of them preferred to migrate due to the high demand and salary from other foreign countries.

This study focuses on the research objectives as per following; to analyse the relationship between lecturers' performance and talent management among lecturers; to determine the relationship between organisational culture and talent management among lecturers; to find the relationship between lecturers' retention and talent management among lecturers.

The findings of the study will assist the HRM to understand the relations on the three major factors of talent management in order for them to plan for ideal solutions and actions. In the part of theory and practice, the operation of business focuses on the operational business in the IT department for small companies. Furthermore, human resource practitioners and talent management specialists will benefit from the developed talent management framework as it will aid and guide the best practices of talent management. Organisations can generate methods to curb the identified problems based on-three factors that contribute to talent management as discussed in the research. In Malaysia, there are many big companies such as Maxis, Petronas Lubricant and others which have been played an important role for every individual and HR departments to decrease the retention rate as compared to the start-up companies (Cutajar, 2012).

\section{Literature Review}

The literature review describes the link between the talent management and the acceding factors along with underlying theories building this conceptual framework.

\subsection{Talent Management}

Talent management has to focus on two major approaches, which are exclusive and inclusive approaches (Festing, 2013). The exclusive approach defines the 'workforce differentiation' concept and recognises talent as a choice of 
subset of the lecturers in the organisation on making a difference to the organisational performance (Devi, 2017). The approach is often from 'humanistic' considerations and advocates allocation of all the organisational resources similarly among lecturers, as everyone in the organisation has their potential 'talent' (Iles, Chuai \& Preece, 2010). Talent management is essential for effective managers and leaders to sustain effective organisation and accomplish the objectives and missions of the companies. It includes a mixture of communication skills, emotional maturity, leadership ability, sharp strategic mind and the capability to inspire others by attracting other talents among the lecturers-(Iles, Chuai \& Preece, 2010). Tafti et al (2017) specified that talented lecturers usually would have a capability to achieve the targeted objectives of the organisation. For the development of lecturer's talent, talent management covers the sourcing, socialisation, maintenance deployment, selection through the activities organised by the HRM. The cycle contains three main fields, which includes the talents maintenance and talent identification, talents development and absorption (Sonnenberg \& Zijderveld, 2014). Basically, the aim of this talent management is to provide alertness on the main workers group as a replacement for the multinational companies (Vardarlier, 2014). Talent management could also reduce expenditures and work money by improving business performance and competitiveness (Raghavendran, 2013). However, Iles and Chuai (2015) claimed that the talent management may lead to bad outcomes, in the context that talent management might encourage the disparity and decrease the productivity. Raghavendran (2013) expressed the same view that the lecturers might have low motivation, be discouraged, be aggravated and this will lead to disappointment as some might not be in the talent pool. This situation could lead to the increase of turnover and lower productivity.

\subsection{Lecturers' Performance}

Lecturers' performance is equally important for the organisation and individual respectively. The performance of the lecturers will lead to the successful implementation of the organisation goals. Kehinde (2012) specified that to sustain the lecturers' performance, the organisation needs to have the necessity concept. Firstly, performance must be well explained and the focus should be on the development of attitudes rather than outcomes. Secondly, attitude behaviour should be in line with the organisational objectives, and thirdly, performance is multidimensional, which includes counterproductive behaviours. Lecturers' performance is related with indicators such as peer review, citation indexes, globally referred publications and productivity (Nzewi, 2015). The use of lecturers' performance to evaluate the academic talent has been passionately debated in the Western academic community. The importance of lecturers' performance has a significant effect for instructional practice (Vardarlier, 2014). As the result, there are no universal agreement on lecturers' performance.

\subsection{Organisational Culture}

Organisational culture has a key role to attract and maintain the good talents. The development of organisational culture aims to attract the suitable candidate for talent management creation and suitable execution are required to have an active talent management (Thunnissen \& Boselie, 2013). Thacker (2014) emphasised that talent management is needed for lecturers to be involved in an organisation. Organisations believe that companies' culture is important in maintaining organisational visions and missions over a set of conventional values. However, there is a wide gap in philosophy with regards to the essential meaning of organisation's culture (Wang \& Chen, 2017). According to Wang and Chen, (2017) many researches have written about organisational culture in academic and management literature, but very few have explored the information about talents. Basically, organisational culture is an evolving idea that happens to be generous towards companies such as public institutions, enterprises, non-profit groups and government departments (Romans \& Lardner, 2015). Romans and Lardner (2015) opine that the idea of organisation culture's absence of clarity and there must be further research to organise its true meaning and its effect on an organisation. According to Romans and Lardner, (2015) the definition of organisational culture has been classified by four characteristics that are symbolised as joint behavioural guidelines, namely, and standards for external and internal communication for an organisation. Essentially, in organisation behaviour the lecturers must have strong impact of ethics, to grow the right work values to have good performance scheme of strategy (Swailes, 2016). Cultures of ethics enable equivalent chances for all workers. By here, it will make the companies manage its workers' multiplicity more efficiently, also move to retain them by attracting extremely driven lecturer workforce. From the perspective of management quality a culture of ethical company will automatically 'work home inviting' for the best available talents (Swailes, 2016).

\subsection{Lecturers' Retention}

Lecturers' retention is normally considered to remain a stable of human resource (Isfahani \& Boustani, 2014). Usually it is linked to life and to companies' belief. According to Isfahani and Boustani, (2014) lecturers' retention of talent has always been a major theme of argument on academic Human Resource Management (HRM) literature 
recently Lecturers' retention is a multipart idea which is about not keeping lecturers within an organisation. Isfahani and Boustani, (2014) supports this certainty about the idea of lecturers' retention. Lecturers' retention has arisen as the most important, critical and complex issue in workforce management. Ochieng (2016) specifies that lecturers' retention is influenced by some determinates that should be accomplished consistently: flexible work schedule/ work life balance, career advancement/development systems, firm's culture, firm's climate, pay and benefits, training and development. Gordon and Adler, (2017) indicate that Development and Career Advancement is one of the key strategies for retention of lecturers. Career advancement and development is generally delivering a flow of talent requirements to an institution or talent it needs. According to Gordon and Adler, (2017) the rising pay levels lessens staff turnover and advances job satisfaction to a significant degree. Organisations should rise and state of their lecturer's key talent. Organisations often thought that their workers resources are pasted to the organisations till they receive payments as welfares are main issues that governs retention. A belief of such can become a farce in the long run (Oladapo, 2014).

\subsection{Family Resource Management Model}

The model comprises of input, throughput and output. Input refers to the resources available to households and demands placed upon those resources. It consists of the internal managerial process of planning and implementing behaviours that connect input and output. Output refers to the sense of wellbeing derived from demands being met (Deacon \& Firebaugh, 1988) and this model assumes that the sense of wellbeing is attained through effective use of resources for inputs and throughputs combine to affect the output. In this model, the organisation is viewed as a decision-making unit that uses its human and material resources to meet demands. The application of the Deacon and Firebaugh on talent management (output) depends upon (a) personal characteristics; (b) lecturers' performance; (c) organisational culture; and (d) lecturers' retention.

Many of the family firms have sole resources that have been cited to as the "families" of the firm (Cabrera-Suarez, De Saa-Perez, and Garcia-Almeida, 2001; Habbershon \& Williams, 1999). Habbershon and Williams (1999) outline families as a group formed by the relationship of business and family. Families do have both advantages and disadvantages. According to Astrachan, (1994) incomes of family businesses and the disadvantages of resource management, can lead to competitive advantage and wealth creation. Resources which have been studied are human capital, patient capital, social capital and survivability.

\subsection{Social Exchange Theory}

Social exchange theory is a moderately wide-ranging theory, which includes principles of behaviourism on understanding and clarification on human interactions. This theory is pertinent and applicable for this intended research. Oparaocha, (2015) highlights that people pursue to exploit their rewards and lessen their costs in political relationships and personal corporate issues. Social behaviour will never be repetitive. Oparaocha, (2015) mentioned that social exchange view can be seen as a conflict and it is unavoidable and even expectable. When groups, workers or lands have experienced or observed inequity or injustice in their system of exchanges, conflict will rise. Social exchange researches suggest that by sustaining an individual one can select on what they want and choose answers to many eventualities of expenses in the society (Cropanzano, 2015).

In talent management, this theory recommends that when the staff are fulfilled with the work environment provided to them, lecturers will likely to stay longer with an organisation, and when they also see no better substitutions (Knippenberg, 2015). Social exchange theory also examines the employment relationship in terms of economic exchanges or social attributes. The discussion of economic benefits is through return of lecturers' actions and through liberal deeds which organisations are persuaded; social exchange could be attained (Knippenberg, 2015).

Social exchange theory highlights on "contingent and interdependent" connects by lecturers as the base for all social relationships and transactions (Neal, 2014). Basically, this theory is a dissimilar method of social communications which is made upon mutual connects and enables psychological agreements, reciprocity, and mutual responsibilities (Neal, 2014). Debatably, social exchange theory delivers an agenda for decrypting the norms and rules that form organisational dealings, reserve connections and value of the mutual responsibilities which is imitated in the developing relationship behaviours in companies (Colquitt, 2012). Hence, this theory delivers a brilliant setting for discovering how intra-organisational social networking architecture may influence capabilities and knowledge management through lecturers' attitudinal inclinations about collaboration and shared culture toward organisational citizenship (Palacios \& Marqués, 2015). 


\section{Conceptual Framework}

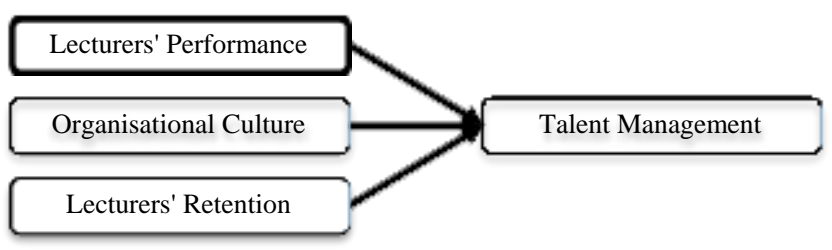

\section{Dependent Variable}

Source: (Tatoglu, Glaister \& Demirbag, 2016; Irtaimeh, Al-Azzam, \& Khaadam, 2016; Nasir, Moktar \& Ariffin, 2017; Alias, Noor \& Hassan, 2014)

Figure 1. The Framework on the Study on Lecturers' performance, Organisational Culture and Lecturers' retention towards Talent Management

Based on the above the following hypotheses are formulated:

$\mathrm{H}_{1:}$ There is a significant relationship between lecturers' performance and talent management.

$\mathrm{H}_{2:}$ There is a significant relationship between organisational culture and talent management

$\mathrm{H}_{3}$ : There is a significant relationship between lecturers' retention and talent management.

\section{Methodology}

The target population of this research will be the lecturers in the Information Technology Department in a university. To determine the sample size for this study, the standard case rules for each variable will be used. According to Hair, Black, Babin, Anderson, and Tatham (2006), a minimum of 20 cases will be chosen per variable, so the total number of samples is 80. Since this study has four variables, a satisfactory number of sample size is: 4 variables $\times 20$ cases $=$ 80. Based on Etikan, Musa, and Alkassim (2016), in this research, purposive sampling method will be used as the targeted respondents will be lecturers from the IT department from a particular university. The samples of respondents can also be attached to any of the branches of that particular university. The research instrument of the variables in this study is displayed in Table 1. Simple random sampling method was used as a probability sampling method.

Table 1. Research Instrument/Measurement

\begin{tabular}{|c|c|c|c|c|c|}
\hline $\begin{array}{c}\text { Sample } \\
\text { type }\end{array}$ & Section & & $\begin{array}{l}\text { Variables that } \\
\text { needed to be } \\
\text { measures }\end{array}$ & Items & Resources \\
\hline \multirow{10}{*}{$\begin{array}{l}\text { Lecturers } \\
\text { of the } \\
\text { instituition }\end{array}$} & \multirow[t]{3}{*}{ B } & & $\begin{array}{c}\text { Dependent } \\
\text { variables }\end{array}$ & \multirow[t]{3}{*}{6} & \multirow[t]{3}{*}{$\begin{array}{l}\text { Jamshidi } \\
\text { (2015) }\end{array}$} \\
\hline & & & $\begin{array}{l}>\text { Talent } \\
\text { management }\end{array}$ & & \\
\hline & & & $\alpha=0.906$ & & \\
\hline & \multirow[t]{7}{*}{$\mathrm{C}$} & & $\begin{array}{l}\text { Independent } \\
\text { variables }\end{array}$ & \multirow[t]{3}{*}{5} & \multirow[t]{3}{*}{$\begin{array}{l}\text { Tash } \\
(2016)\end{array}$} \\
\hline & & & $>\begin{array}{c}\text { Lecturer } \\
\text { performance }\end{array}$ & & \\
\hline & & & $\alpha=0.636$ & & \\
\hline & & $>$ & $\begin{array}{l}\text { Organisationa } \\
1 \text { culture }\end{array}$ & \multirow[t]{2}{*}{5} & \multirow[t]{2}{*}{$\begin{array}{l}\text { Devi } \\
\text { (2017) }\end{array}$} \\
\hline & & & $\alpha=0.793$ & & \\
\hline & & & $\begin{array}{r}\text { Lecturer } \\
\text { retention }\end{array}$ & \multirow[t]{2}{*}{5} & \multirow[t]{2}{*}{$\begin{array}{c}\text { Kohestany } \\
\text { (2017) }\end{array}$} \\
\hline & & & $\alpha=0.860$ & & \\
\hline
\end{tabular}




\section{Data Analysis and Discussion of Findings}

\subsection{Descriptive Analysis}

Demographic information about each of the respondents consists of several items, namely: gender, nationality, age, and education level in the IT department. To collect the data from this study, 140 questionnaires were administered to lecturers in the IT department in the University, where 133 respondents provided information about themselves.

Table 2. Multiple Regression Analysis

\section{Dependent Variable Independent Variables $\quad$ Coefficient Value $\quad \beta \quad$ Significant Value (Sig.) $\quad R^{2}$}

\begin{tabular}{llll}
\hline \multirow{3}{*}{ Talent Management } & Lecturers' performance & .052 & .660 \\
\cline { 2 - 4 } & Organisational Culture & .064 & .580 \\
\cline { 2 - 4 } .409 \\
\cline { 2 - 4 } & Lecturers' retention & .060 & .002
\end{tabular}

The total number of respondents was 133 people, of which 68 (51.1\%) were men and 65 (48.9\%) were women, so the number of men is not more than women. According to the analysis, 84 lecturers (63.2\%), are Malaysians who are attached to the university. On the other hand, 49 lecturers (36.8\%) are foreigners who have been working in Malaysia for quite some time. The survey results show that 30 lecturers (22.6\%) working in the IT department in the university are between the ages of 18 to 24 . However, the highest number of lecturers is $54(40.6 \%)$ are in the age group from 25 to 34 . In addition, 41 respondents were included in the age group from 35 to 44 years, which makes up to (30.8\%) of the total number of respondents. Moreover, eight people (6.0\%) were included in the group of people from 45 and above. The study level of the education showed that 24 lecturers (18.0\%) completed Diploma, 77 respondents (57.9\%) have completed their undergraduate programme (Bachelor's Degree) and 32 lecturers (24.1\%) have completed postgraduate programme.

\subsection{Reliability Test}

According to Nunnally (1981, the Cronbach Alpha coefficient should not be below 0.7, however according to Sekaran (2003), the Cronbach Alpha coefficient should be greater than 0.5. The researcher will adhere to the proposal of Sekaran (2003), in which the Cronbach Alpha value should be at least 0.5.

\subsection{Multiple Regression Analysis}

With reference to Table 2, the value of $\mathrm{R}^{2}$ is 0.409 . This indicates that $40.9 \%$ of the total variance in the dependent variable (talent management) is explained by the total independent variables (lecturers' performance, organisational culture and lecturers' retention). Hence, the remaining 59.1\% might account by other variables that are not included in this research.

The arrangement of strengths among the independent variables (lecturers' performance, organisational culture and lecturers' retention) that contributes to the dependent variable (talent management) is the Lecturers' performance ( $\boldsymbol{\beta}$ $=.052)$, Lecturer Motivation $(\boldsymbol{\beta}=.064)$ and Work Life Balance $(\boldsymbol{\beta}=.060)$.

The significant value of each variable indicates whether the hypothesis should be accepted or rejected. If the significant value is lower than 0.05 , the hypothesis is accepted. In contrast, the hypothesis is rejected if the significant value is above 0.05 . Table 3 shows the results of hypothesis.

Table 3. Hypotheses Results

\begin{tabular}{|c|c|c|}
\hline Hypotheses & Significant & Results \\
\hline $\begin{array}{l}\mathrm{H}_{1} \text { : There is a no significant relationship between lecturers' performance } \\
\text { and talent management. }\end{array}$ & .660 & Rejected \\
\hline $\begin{array}{l}\mathrm{H}_{2} \text { : There is a no significant relationship between organisational culture } \\
\text { and talent management. }\end{array}$ & .580 & Rejected \\
\hline $\begin{array}{l}\mathrm{H}_{3} \text { : There is a significant relationship between lecturers' retention and } \\
\text { talent management. }\end{array}$ & .002 & $\begin{array}{l}\text { Fail to } \\
\text { reject }\end{array}$ \\
\hline
\end{tabular}




\section{Conclusion and Recommendations}

The discussion below is based on the objectives and hypotheses testing. The hypotheses were discussed in line with the data analyses obtained.

\subsection{The Relationship between Lecturers' Performance and Talent Management}

One of the main objectives of this study was to find a significant relationship between talent management and lecturers' performance. Thus, the results of the study of the hypothesis indicated that the positive relationship between talent management and lecturers' performance is rejected. According to the empirical study of Keller (2014), there is direct relationship between talent management and lecturers' performance. It mentions that talented lecturers have the capability and the opportunity because they are placed in strategic positions and thus are inspired to perform and hereafter, motivation tends to arbitrate the relationship between talent management and lecturers' performance. Moreover, the researcher perceives that organisation tends to be more supportive which add that investing in talented lecturers increases their motivation and pledge to the organisation. Like the research conducted by Saini (2014), which concluded that lecturers' performance is one of the factors of talent management. In the study it was stated that talented lecturers are capable on their job on task performance, be able to commit extra effort on the lecturer task and be more innovative and generate new ideas (Saini, 2014). Talent management also plays an important role on the identification of talented individuals, and this may lead to the avoidance of behaviours that negatively affect the organisation. Also, Collings (2013) found that lecturers' performance does have a link in talent management. It highlighted that the modest contribution of findings in talent management does not only lead to positive performance but also reduces counterproductive behaviours. Also, the implementation of talent management will lead to lecturers' performance in relations of core job functions, contextual behavours, as well as creativity and innovativeness.

\subsection{The Relationship between Organisational Culture and Talent Management}

The next objective of this research is to find the relationship between talent management and organisational culture. Based on the results of this study, the hypothesis that demonstrates a positive relationship between talent management and organisational culture is rejected. Gallardo (2013) too supported the statement of positive relationship between talent management and organisational culture. Gallardo (2013) claims that the organisational ability in managing talents influences organisational culture. It is necessary to focus more on creating conditions allowing for employment of the potential of talented lecturers. With reference to the research by Rachel (2016), the organisational culture is diametrically related to talent management. This is because an organisation simultaneously creates such a group and, by force of his or her personality, begins to shape the group's culture and from here the culture of an organisation is extremely stable and sustainable and it affects every aspect of the organisation. Futhermore, Kontoghiorghes (2015) revealed that diversity is very much important in an organisation's culture in order to sustain for longer and much importance given towards talent management. Further, a lecturer who is harmonious inside and identifies with an organisational culture achives the transformation from the talent to its excellence. Hence, it is a more valuable pattern of meshing organisational culture to cultivate more excellent talents for the organisation.

\subsection{The Relationship between Lecturers'Retention and Talent Management}

Another important objective of this study was to find a significant relationship between talent management and lecturers' retention. Thus, the results of the study of the hypothesis indicated a positive link between talent management and lecturers' retention is accepted. According to the research by Elsaid (2017), the primary factor of lecturers' retention is because the younger generation, are more highly educated Most of the organisations usually do hire a lecturer and they fail to keep them and tap on their expertise. Weerasinghe (2017) mentions that a HR manager needs to work closely with senior level managers to recruit, attract, grow and retain their top talented lecturers within the organisation. To make sure the senior level managers know what is happening in the organisation and they need to be aware that talented lecturers will leave the organisation if they did not take care of the lecturers since the senior level mostly look on their profits (Weerasinghe, 2017). This will happen to be a serious matter if senior level administrators think that lecturers are not important. Also, Boustani (2014) mentions that talent management in lecturers' retention has an effect over lecturers' trust and labour retention rate of the organisation. This is because the retention refers to the organisation's ability to maintain talented and qualified staff such as people who can help the organisation's competitiveness in this rapidly changing world.

\subsection{Implications of the Study}

The below discusses the implications from lecturers, employers and the literature perspective. The study of the problem of talent management of lecturers and the factors that affect can help to increase the level of talent 
management of lecturers in the IT department in universities. In this study, the problem is identified, and its symptoms are revealed, moreover, each of the factors that affect talent management is described. Thus, this study enables lecturers to take into account all the factors that affect talent management and enable each lecturer to be more successful in their organisation, thereby climbing the career ladder and increasing their own income. Moreover, this research can help lecturers not to change often the organisation, but rather to move forward, work and develop the brand of one organisation, which in turn will be more successful in competing in the labour market.

In addition, a study of the problem of talent management of employers and the factors that affect it can help the employer improve the talent management of its lecturers by examining the factors that affect it. Moreover, the employer can limit himself from the risks of a large loss of lecturers in small companies, while investing in them money and knowledge. Each lecturer for the employer is a very important person, with the help of which, the whole business system is working properly. However, when an employee does not portray the rightful talents in them, the employer loses his money and the trust of his clients, which may lead to the organisation's collapse. Thus, the study can help the employer increase the profit of his organisation, by improving the quality of talents of each lecturer.

Besides, this study can help develop the IT department of the university. Thus, the IT department can improve talent management to enable the organisation operational environmental sustainability and increase organisational performance. It is pertinent that, the IT department in the university needs to manage the lecturers' specific talents so as to eventually excel in brand performance. In addition, talent management enables the organisation to successfully compete in the market and to retain the talented lecturers in the organisation, so as they as they do not look for other companies. The organisation needs to create value of the lecturers. Moreover, relating to the present developing economic and diplomatic relations of Malaysia with various countries all over the world, the IT department accepts high-ranking intellectuals at the State level and in this case many lecturers will evaluate the country at its IT. This study can therefore help the IT department in the upbringing and the cultivation of talent management.

In addition, this study can help future researchers determine the factors that affect talent management and the problem of talent management in the organisation. Thus, it will be possible to determine the factors influencing talent management of the lecturers. The results of this study could set the basis for future researches in this particular field In addition, this research is unique, since such studies have not been carried out, moreover, the problem of talent management is present not only in the IT department, but also in various structures related to work with the personnels. The data from this study could be useful for future researchers.

\section{Conclusion}

The results of past studies were included to justify the results of this study. In addition, the results of this study were substantiated and the reasons for the appearance of these results were revealed. Moreover, the implications of this study was presented and described. Further, the limitations of this study were presented and at the end of the chapter, various recommendations for future researchers were presented, which, in the author's opinion, would be the best recommendations for researching and solving the problem of talent management.

\section{References}

Ahlan, A. R. (2014). Academic Conferences International Limited. An Empirical Study on the Risk Management Strategies of IT Outsourcing in Malaysia Public Sector, 9-VIII.

Alias, N. E., Noor, N. M. \& Hassan, R. (2014). Examining the Mediating Effect of Employee Engagement on the Relationship between Talent Management Practices and Employee Retention in the Information and Technology (IT) Organizations in Malaysia. Journal of Human Resources Management and Labor Studies, 227-242.

Astrachan, J. A. (1994). A neglected factor explaining family business success: human resource practices". Family Business Review, 251-62. https://doi.org/10.1111/j.1741-6248.1994.00251.x

Benitez, A. J. (2015). Springer Science+Business Media New York. IT impact on talent management and operational environmental, 207-220. https://doi.org/10.1007/s10799-015-0226-4

Boustani, H. (2014). Effects of Talent Management on Employees Retention: The Mediate Effect of Organizational Trust. International Journal of Academic Research in Economics and Management Sciences, 114-128.

Brink, M. v. d. \& Fruytier, B. (2012). Talent management in academia: performance systems and HRM policies. Human Resource Management Jourrnal, 5(5), 2-16.

Business Monitor International. (2016). Malaysia Information Technology Report - Q2 2016, 1-64.

Iles, P., Chuai, X. \& Preece, D. (2010). Talent Management and HRM in Multinational companies in Beijing: 
Definitions, differences and drivers. Journal of World Business, 45, 179-182. https://doi.org/10.1016/j.jwb.2009.09.014

Cabrera-Suarez, K., De Saa-Perez, P. \& Garcia-Almeida, D. (2001) The Succession Process from a Resource-and Knowledge-Based View of the Family Firm. Family Business Review, 14, 37-48. https://doi.org/10.1111/j.1741-6248.2001.00037.x

Collings, M. (2013). Seven myths of global talent management. The international Journal of Human Resource Management, 1762-1776.https://doi.org/10.1080/09585192.2013.777539

Colquitt, J. L. (2012). Explaining the justice - performance relationship: trust as exchange deepener or trust as uncertainty reducer? Journal of Applied Psychology. https://doi.org/10.1037/a0025208

Cropanzano. (2015). Social exchange theory: an interdisciplinary review. Journal of Management, 874-900. https://doi.org/10.1177/0149206305279602

Cropanzano, R. \& Mitchell, M. (2014). Social Exchange Theory:An Interdisciplinary Review. Research Gate, 31(6), 4-29. https://doi.org/10.1177/0149206305279602

Cutajar, B. (2012). THE IMPACT OF ORGANISATIONAL CULTURE ON THE. THE CASE OF MALTESE ICT ORGANISATIONS, 6-254.

Deacon, R.E. \& Firebaugh, F.M. (1988). Family resource management: Principles and applications. (2 nd ed.). Needham Heights, MA: Allyn and Bacon.

Deery, M. \& Jago, L. (2015). Revisiting talent management, work-life balance and retention strategies. International $\begin{array}{lllll}\text { Journal of Contemporary Hospitality } & \text { Management, } & \text { 27(3), }\end{array}$ https://doi.org/10.1108/IJCHM-12-2013-0538

Department of Statistic Malaysia, Official Portal. (2016). Federal Territory of Kuala Lumpur. Retrieved March 18, 2016 ,

from https://www.statistics.gov.my/index.php?r=column/cone\&menu_id=bjRIZXVGdnBueDJKY1BPWEFPRlhIdz0 9

Devi, S. (2017). Impact Of Talent Management On Organizational Performance: Role Of Employee Engagement. International Journal of Management Studies, 17-27.

Elsaid, E. (2017). An Exploratory Study on How Talent Management Affects Employee Retention and Job Satisfaction for Personnel Administration in Ain Shams University Egypt . Journal of Management and Strategy, 1-17. https://doi.org/10.5430/jms.v8n4p1

Fanxing, M. (2016). The influence of organizational culture on talent management. Journal of Chinese Human Resource Management, 7(2), 129. https://doi.org/10.1108/JCHRM-07-2016-0010

Gallardo, N. (2013). A multidisciplinary review into the definition, operationalization, and measurement of talent,. Journal of World Business .

Gordon, R. (2015). Regression Analysis for the Social Sciences. New York: Routledge. https://doi.org/10.4324/9781315748788

Gordon, S. \& Adler, H. (2017). Employee perceptions of well-being and organizational wellness offerings: A study of line-level employees in select-service hotels. Journal of Human Resources in Hospitality \& Tourism, 308-330. https://doi.org/10.1080/15332845.2017.1253443

Habbershon, T.G. \& Williams, M.L. (1999) A Resource-Based Framework for Assessing the Strategic Advantages of Family Firms. Family Business Review, 12, 1-25. https://doi.org/10.1111/j.1741-6248.1999.00001.x

Hair, J.K., Black, B. R., Babin, H. B., Anderson, P. R. \& Tatham, C.R (2006). Multivariate data analysis. 6th edition. New Jersey. Pearson Education, Inc.

Hughes, J. C. \& Rog, E. (2012). Talent management: A strategy for improving employee retention. International $\begin{array}{lllll}\text { Journal of Contemporary } & \text { Hospitality }\end{array}$ https://doi.org/10.1108/09596110810899086

Iles, P. \& Chuai, X. (2015). Talent Management and HRM in multinational companies in Beijing: defining, difference and drivers. Journal of World Business, 179-189. https://doi.org/10.1016/j.jwb.2009.09.014

Irtaimeh, Al-Azzam \& Khaddam. (2016). Exploring the Impact of Talent Management Strategies and Service Quality 
on Beneficiaries' Satisfaction in Jordan Healthcare Sector: Provider Point of View. Journal of Enterpreneurship \& Organisational Management, 1-9.

Isa, A. \& Ibrahim, H. I. (2014). Talent Management Practices And Employee Engagement: A Study In Malaysian Glcs. International Journal of Business, Economic and Law, 4, 64-70.

Isfahani, A. C. \& Boustani, H. (2014). Effects of Talent Management on Employees Retention. International Journal of Academic Research in Economics and Management Sciences, 3(5), 3-15. https://doi.org/10.6007/IJAREMS/v3-i5/1196

Jamshidi, A. M. (2015). Studying the Impact of Talent Management on Performance of Staffs of Different Branches of Refah Kargaran Bank in Tehran. Asian Journal of Research in Social Sciences and Humanities, 270-279. https://doi.org/10.5958/2249-7315.2015.00152.5

Kehinde, J. S. (2012). Talent Management: Effect on Organizational Performance. Journal of Management Research, 4(2), 3-9. https://doi.org/10.5296/jmr.v4i2.937

Keller, C. (2014). Talent management: conceptual approaches and practical challenges. Annual Review of Organisational Psychology and Organisational Behaviour, 305-331. https://doi.org/10.1146/annurev-orgpsych-031413-091314

Knippenberg, V. (2015). Beyond social exchange: collectivism's moderating role in the relationship between perceived organizational support and organizational citizenship behaviour". European Journal of Work and Organizational Psychology, 152-160. https://doi.org/10.1080/1359432X.2013.858699

Kohestany, Z. (2017). Investigating the Impact of Talent Management on the Retention of Human Resources: A Study in Zahedan Municipality. International Review of Management and Marketing, 138-142.

Kontoghiorghes, C. (2015). Linking high performance organizational culture and talent management: satisfaction/motivation and organizational commitment as mediators. The International Journal of Human Resource Management, 1833-1853. https://doi.org/10.1080/09585192.2015.1075572

Kwame, J. (2015). A coalesced framework of talent management and employee performance. International Journal of Productivity and, 64(4), 544-566. https://doi.org/10.1108/IJPPM-07-2014-0100

Marion Festing, L. S. (2013). Generational challenges to talent management. Journal of World Business, 262-271. https://doi.org/10.1016/j.jwb.2013.11.010

Meng, F., Wang,, X. \& Chen, H. (2017). The influence of organizational cuture on talent management. Industrial and Commercial Training, 49(1), 15-21. https://doi.org/10.1108/ICT-05-2016-0036

Mishra, N. \& Chung-Chih, L. (2015). A Cognitive Adopted Framework for IoT Big-Data Management and Knowledge Discovery Prospective. International Journal of Distributed Sensor Networks; Abingdon. https://doi.org/10.1155/2015/718390

Mohamed, A. I. \& Shiekh Abukar, A. (2013). The Impact Of Organizational Culture On Employees. Academic Research International, 4(6), 5-10.

Naim, M. F. \& Lenka, U. (2017). Talent management: a burgeoning strategic focus in Indian IT industry. Industrial and Commercial Training, 49(4), 183-188. https://doi.org/10.1108/ICT-12-2016-0084

Nunnally, J.C. (1981). Psychometric theory. (2nd Ed). New Delhi: Tata McGraw-Hill publishing Co Ltd.

Nasir, Y. S., Moktar, S. \& Ariffin, A. S. (2017). Effectiveness of talent management to improving organisational performance in government owned bank. Journal of Advanced Research in Business and Management Studies, $32-38$.

Neal, Z. (2014). A network perspective on the processes of empowered organizations. American Journal of Community Psychology, 407-418. https://doi.org/10.1007/s10464-013-9623-1

Nisada, W. (2016). Unlocking the "black box" in the talent management employee performance relationship. Management Research Review, 39(12), 1546-1566. https://doi.org/10.1108/MRR-08-2015-0190

Ochieng, P. A. (2016). Relationship Between Talent Management Practices And Employee Retention At Dhl Supply Chain Kenya Limited, 6-60.

Oladapo, V. (2014). The Impact Of Talent Management. Journal of Business Studies Quarterly, 5(3), 3-18.

Oparaocha, G. O. (2015). Towards building internal social network architecture that drives innovation: a social 
exchange theory perspective. Journal of Knowledge Management, 534-556. https://doi.org/10.1108/JKM-06-2015-0212

Palacios-Marqués, D. M.-A. (2015). Online social networks as an enabler of innovation in organizations. Management Decision, 1906-1920. https://doi.org/10.1108/MD-06-2014-0406

Rachel, D. L. (2016). Impact of Talent Management on Organisation Culture. The International Journal of Business and Management, 96-119.

Raghavendran, S. (2013). Not by money alone: the emotional wallet and talent management. Journal of Business Strategy, 34(3), 16-23. https://doi.org/10.1108/JBS-11-2012-0073

Romans, J. \& Lardner, L. (2015). Integrated talent management at BD Japan: How a holistic approach to talent management built a high performance culture. Strategic HR Review, 4(5), 16-19. https://doi.org/10.1108/14754390580000816

Saini, C. (2014). Talent management in China and India: a comparison of management perceptions and human resorces practices. Journal of World Business, 225-269. https://doi.org/10.1016/j.jwb.2013.11.006

Sekaran, U. (2003). Research Method for Business: A Skill Building Approach. (4th Ed.) New York: John Wiley \& Sons.

Sonnenberg, M. \& Zijderveld, V. (2014). The role of talent-perception incongruence in effective talent management. Journal of World Business, 272-280. https://doi.org/10.1016/j.jwb.2013.11.011

Swailes, S. (2016). The Cultural Evolution of Talent Management. Human Resource Development Review, 4-19. https://doi.org/10.1177/1534484316664812

Tafti, M. M., Mahmoudsalehi , M. \& Amiri, M. (2017). Critical success factors, challenges and obstacles in talent management. Industrial and Commercial Training, 3-8.https://doi.org/10.1108/ICT-05-2016-0036

Tash, M. S. (2016). The Effects of Talent Management on Employees Performance in Oil Jam Petrochemical Complex (Oil JPC): The Mediating Role of Job Satisfaction. International Journal of Economics and Finance, 226-230. https://doi.org/10.5539/ijef.v8n6p226

Tatoglu, E., Glaister, A. \& Demirbag, M. (2016). Talent management motives and practices in an emerging market: A comparison between MNEs and local firms. Journal of World Business, 278-294. https://doi.org/10.1016/j.jwb.2015.11.001

Thacker, R. (2014). An examination of the relationship between upward influence tactics and assessments of promotability. Journal Of Management, 739-756. https://doi.org/10.1016/0149-2063(95)90008-X

Thunnissen, M. \& Boselie, P. (2013). A review of talent management: "Infancy or adolescene?". International Journal of Human Resource Management, 24, 1744-1761. https://doi.org/10.1080/09585192.2013.777543

Trequattrini, R. \& Shams, R. (2016). Risk of an epidemic impact when adopting the Internet of Things: The role of sector-based resistance. Business And Economics-Management, 403-419. https://doi.org/10.1108/BPMJ-05-2015-0075

van Zyl, E. R. (2017). The development of a talent management framework for the private sector. Business And Economics--Personnel Management, 15, 5-18.https://doi.org/10.4102/sajhrm.v15i0.820

van Zyl, Ebben S, Mathafena, Rose B \& Ras, Joyce. (2017). The development of a talent management framework for the private sector. SA Journal of Human Resource Management, 2-16. https://doi.org/10.4102/sajhrm.v15i0.820

Van, M. (2013). Talent management in academia: performance. Human Resource Management Journal, 3-16.

Vardarlier, V. (2014). The effects of using talent management with performance evaluation system over employee commitment. Procedia - Social and Behavioural Sciences, 340-349.

Weerasinghe, G. (2017). Impact of talent management on employee retention: A study carried out on travel agency in Sri Lanka. International Journal of Multidisciplinary Research and Development, 54-58.

Williams, K. \& Karau, S. (2014). Social loafing and social compensation: the effects of expectations of co-workers perfomance. Journal of Personality and Social Psychology, 570-581. https://doi.org/10.1037//0022-3514.61.4.570 